\title{
Dependency among Kautilya's Three Major Ideas: Upaya, Sadgunya, and Prakrti
}

\section{Krishna Kumar Saha*}

Department of Public Administration, Comilla University, Cumilla-3506, Bangladesh.

*Correspondence: krishna_du@yahoo.com (Krishna Kumar Saha, Assistant Professor, Dept. of Public Administration, Comilla University, Bangladesh)

\begin{abstract}
Since the rediscovery of Kautilya's Arthasastra, it is considered as one of the oldest books on statecrafts and political realism in the world. In the book Arthasastra, Kautilya has described many ideas of statecraft, and they are still in the use of state polity. Until now some of his ideas remained unextractable. Many scholars in South Asia and the West are practicing the ideas formulated by Kautilya. Yet, as a native South Asian political fractional and international relations theorist, Kautilya remained under exposed. Nevertheless, this current study is an attempt to find the dependency among the three significant concepts by Kautilya from his Arthasastra. In the study, the researcher has attempted to show how shifts in one of the three major concepts can change the other two. They are entirely dependent on each other. The researcher has made an effort to create a 'measurement scale' to measure the dependence among the 'Upaya, Sadgunya, and Prakrti.' On the other hand, since these concepts can also be found in the modern-day state system, the study has analyzed the ' 1962 SinoIndian War' concerning those three concepts. This current research is an explorative investigation.
\end{abstract}

Keywords: Kautilya, Upaya, Sadgunya, Prakrti, Arthasastra, Sino-Indian war, Dependency, and Political realism.

\section{INTRODUCTION}

Kautilya's Arthasastra is the foundational work of political realism in international relations theory, and achievements are on a plane with Machiavelli. On a similar note, Max Weber's repeated reference to Arthasastra can make us understand the importance of these several century-old work. There are not many political scientists, or international relations theorists from Global South marked their presence in Western academia (Ahmed et al., 2019). On the other hand, Kautilya is one of them, among the very few. He is the first of a kind who talked about state security and power. Centuries later, many theorists wrote about those ideas, but there remains a clear difference.
Because unlike the Western philosophers, Kautilya talked about the holistic concept of state security and power. He says it is essential to have a strong treasury so that the state can ensure good governance and robust defense mechanism.

One of the significant international relations theorists in the twentieth-century Hans J. Morgenthau has coined the theory of political realism. And many scholars also claim that this theory is also based on Indian philosophy. However, as you can see now, Kautilya has remained on the sidelines of the Western discourse of international political science even though his works have been practiced by many western scholars already (Liebig, 2014; Liebig \& Mitra, 2017). 
However, this Arthasastra is a theoretical and normative work and comprises clusters of ideas mostly on statecraft and international relations (Spruyt, 2020; Prasad, 2018).

In this current study, the researcher has attempted to explain the exclusive three concepts from Arthasastra. They are Upaya, Sadgunya, and Prakrti. However, it is better to mention here is that Upaya is not the original concept by Kautilya. It was borrowed from the ancient epics Mahabharata and the Ramayana (Hillebrandt, 1923; Saad \& Wenxiang, 2020). Besides, the researcher will try to find the dependency of these three concepts (Upaya, Sadgunya, and Prakrti). Also, the researcher will try to develop a 'measuring scale' to measure the ratio of dependency on these three significant components of statecraft. Likewise, the researcher will go further to find if there is any change in any sub-concepts affects the whole idea of these three concepts and will try to relate to the event from the 1962 Sino-Indian War (Prabhu, 2019).

In this current study, the researcher attempted to develop three different values for 7 Prakrti. The status of the Prakrti will be valued by ' 0 ' for 'stable' and '-1' is 'decline and ' 1 ' is 'advancement' position, respectively. Then the researcher will determine the other positions of Upaya and Sadgunya by evaluating those values from Prakrti. Once the position has been determined, then they will be placed on a measurement scale. Based on the scale, readers will be able to understand the dependency of the major concepts of Kautilya.

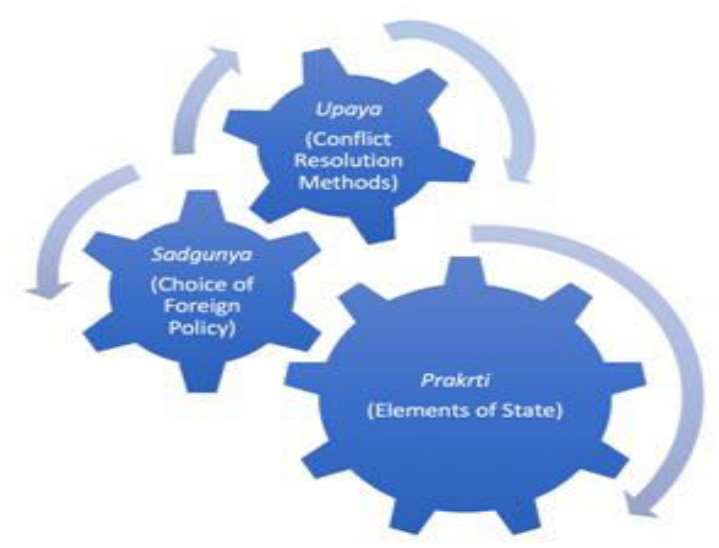

Fig 1: Inter-Dependency among the Three Major Concepts by Kautilya (adopted by the researcher).

\section{Hypothesis and Research Question}

The hypothesis of the study is, change in any one of the three concepts (Prakrti, Sadgunya, and Upaya) will affect the other two. My research questions of the study are, does change in any of these three will impact the other remaining two?

To answer the research question, the researcher will try to find the relevant examples from the present-day world politics and statecraft. The Arthasastra is value, time, and context-free reading (Boesche, 2003). Hence the case from any corner of the world will not affect the application of the book. Kautilya's method gives the result of the test of my hypothesis, and the methodology for that experiment; given his works are time and context-free (Modelski, 1964).

\section{METHODOLOGY}

The paper is based on an extensive review of published and unpublished works on Kautilya and his works around the world. These works include the relevant annual as well as special reports and publications by the following organizations. They are namely- United Services Institution in India, South Asia Institute, Heidelberg, Germany; Institute for Defense Studies and Analyses New Delhi, India; as well as that of other national and international agencies were also considered for literature collection for the given topic. The researcher has reviewed articles and research papers published in scientific journals for the consolidation of this current paper. In short, the paper is a review article based on secondary data. Furthermore, the paper is exclusively based on reviews of English language articles and reports. Besides, the study is mostly a secondary literature survey. The researcher has tried to find the literature evidence from different books and articles recommended by my peers. Furthermore, this study is a qualitative research work. The final argument of this study is the 1962 Sino-Indian War was a miscalculation of "co-relation of forces' from the Indian point of view. The realist might argue that due to the self-help security system, India went to war; however, the idealist would say the war is not an option for peaceful co-existence. In this case, the researcher will try to find the position of the Indian leaders according to the Kautilyan view (Hossain, 2020). 
Kautilya - You know that Kautilya or Chanakya was a Brahmin, and he served as Chief Minister of Chandragupta (Modelski, 1964). Kautilya was initially responsible for the education and later policy guidance for Chandragupta and his administration. Some other early texts show that Kautilya set Chandragupta on the throne. However, his name is also associated with the famous book on statecraft from ancient Hindu World' Arthasastra'. The Indologists have been debating about the authorship of the book. The book is itself from 300 B.C. old and has no established proof that Kautilya is not the author of it (Liebig, 2014; Liebig \& Mitra, 2017).

Arthasastra - This book, named 'Arthasastra,' is the combination of two Sanskrit words. If you divide the 'Arthasastara' into two parts, there is 'Artha' and 'Sastra.' Now let's translate those words. 'Artha' means 'object' or 'thing.' On the other hand, in this context, the proper translation will be 'Statecraft' or 'Politics.' Likewise, 'Sastra' means 'Textbook' or 'Handbook' (Gautam, 2013a). Hence, if you try to make a literary meaning of Kautilya's 'Arthasastra' it would be 'Handbook of Statecraft' or 'Textbook of Politics' (Kinzinger, 2015; Kainiraka, 2016).

The Arthashastra is a collection of 15 books, called 'adhikarans,' and each book consists of chapters that comprise verses; these are called 'sutras'. The book is composed of different concepts of statecraft. Before describing the major concepts by Kautilya, the researcher would like to give the readers an overview of the 15 books of the Arthasastra. In the following, a summary of those books is given.

The first book in Kautilya's Arthashastra describes the challenges for the ruler. To be specific, the ruler (the king) must face the challenges of his education, the way to appoint officials, his ministers, the diplomats, and his administrators. Likewise, the state departments and their tasks are at the center of the investigation, and focus is on the tax policy are the things discussed in the second book. The third book discusses justice and law. Also, Kautilya confirms the 'caste system' is the center of society (Gautam, 2013b; Kainiraka, 2016).

UniversePG I www.universepg.com
The fourth book is the extension of the third book and continues the discussion on the legal system and penal law. Likewise, how to recruit, educate, and use spies is the major concern of the fifth book. Besides, it describes the system of agents and spies. In the sixth book, Kautilya describes the two major conceptsRajamandala (circle of kings) and Saptanga (elements of state). In addition, book seven describes the Kautilya's account of six foreign policy measures Sadgunya (choice of foreign policy).

When the prakrti (saptanga) are in danger or do not develop positively, what measures should be taken, are described in book eight. Simultaneously, book nine describes how to plan the invasion of another state and which preparation should be done before starting a military operation. All aspects of military intervention and how to deal with the army are discussed in the tenth book. This tenth book is connected with book nine. In book eleven, Kautilya shows that how the state can, through the use of intelligence service, destroy inner enemies and sabotage an adverbial group in his country.

How the ruler can gain control over the weaker states through the help of the secret service and diplomacy is described in book twelve. In book thirteen, Kautilya made a guideline on how to conquer the enemy's capital without being cruel to the population and without destroying the city. Some occult measures and magical practices as psychological warfare are discussed in book fourteen. And finally, the book fifteen is a glossary and where Kautilya explained the terms he used in Arthashastra.

Another exciting thing about Kautilya's Arthashastra is when he starts writing; he begins by stating that most of the things he will lay down in the following have already been saying. It determines that there was more political thinker before him. However, nobody didn't write the thing in an elegant way he did. He is the one who sums up everything and brings the conclusion before anyone else did. However, he points out that none of them could draw a conclusion that he has made and that he has written down in the Arthashastra (Boesche, 2002). 
Major Concepts by Kautilya- Now the researcher will give a short introduction of major concepts presented by Kautilya in his Arthashtra. Let's start with the 'matsya-nyaya.' And it means the 'law of the fishes' which corresponds in western terminology to 'the law of the jungle,' 'might is right' or 'anarchy.' Having 'selfish' disposition, humankind consistently gets in conflicts of interests with each other. If they are left their own, these conflicts are resolved by the stronger party enforcing its will against the resistance of the weaker ones. For Kautilya, this is the natural state of human existence (Liebig, 2014; Kanwal, 2016).

To manage the conflicts, Kautilya submits a kind of 'contract theory.' Since people have suffered from the condition of matsya-nyaya - fearing for their life and property, then they want a ruler with supreme executive power and armed with 'rod' (force) and punishment. With the establishment of a supreme ruler, the 'might makes right' is monopolized by the state. With this monopolized power state can punish who would illegally use force (murder, assault, or robbery, etc.) within its territory. The thing is, for the absence of a magistrate, the strong will swallow the weak; but under his protection, the weak resist the strong. If the state were incapacitated, matsya-nyaya would return (Kainiraka, 2016).

There is another major concept Saptanga (elements of state) from which the state is made of (Gautam, 2013b, p. 33). They are- swamin or the ruler; amatya or the administration and the ministers; janapada or the population or rural population; durga is the capital city and the fortress; kosa is the treasury; danda is the executive power of the state and armed forces; mitra is the foreign allies. These are the seven prakrti or the saptanga theory, and the order of these prakrti has logically set.

The Swamin or the ruler is the head of state, and he must be educated according to the Arthashastra. Moreover, Kautilya makes it clear that king is the first servant of the state and should take control over amatya or the administration and must secure their loyalty and effectiveness. The well-being of the janapada or the population or rural population working in the agricultural field must be ensured by the amatya so that they can make much profit by doing their agricultural livelihood. Through this, they can pay taxes. The durga is the capital city and the fortress, which is the heart of the empire, and here the king, the royal household, and administration are situated. The fifth factor kosa is the treasury also located here. With the efficiency of the ministers, the capital city has to be secured. Without that, the capital wouldn't exist, and another king would capture kosa. To prevent this capture of kosa, the swamin needs danda is the executive, and its job is to protect all other prakrti in the case of attack. These are mainly concerned about the domestic policy of a state (Ray, 2015). The last factor is mitra the foreign allies and deals with the foreign relations of the state.

The first two prakrti are concerning the personnel of the state, whereas the other four are more complex and cannot be easily replaced as the first two. In addition, the first six prakrti are concerned about domestic things of a state, but the last one is about foreign policy. All the Prakrti have an inter-dependency relation. The main task of the ruler is to secure the functioning of all factors of the state. And when the ruler wants to prepare for the war, he should make the elements even more prosperous. Kautilya mentioned that if all of the factors are not entirely intact, it is not possible to go into the military offense to expand the territory of the state. Besides, it is even dangerous for the state so that another ruler can attack. Kautilya' sex plicit instruction to the ruler is that the optimization of the seven state factors must be 'raison d' état.' $\mathrm{He}$ himself didn't mention the word 'raison d' état.' Still, ifyou define the term as 'the unconditional imperative of the state's self-preservation,' the idea was there in the Arthasastra (Liebig, 2014).

Another major concept by Kautilya in his book Arthashastra is Sadgunya. As already mentioned, it deals with foreign policy. Hence, Shadgunya is the six measures of foreign policy. They are - samdhi (peace); vigraha (war); asana (neutrality); yana (diplomatic pressure); samshraya (cooperation); and dvaidhibhava (diplomatic double-game). These are the measures of foreign policy. One ruler can choose any foreign policy measure by testing or compare the seven Prakrti of the state. 
If you go back to the prakrti, you will see that mitra is an ally in foreign policy. Mitra can be the ruler of another state but also some opposing forces in a foreign, hostile state, which tries to overthrow the current ruler of this state, and for this, the swamin supports them as mitra. Since the ruler aims to reach the supremacy of the Indian Sub-continent, the ruler has to choose which form of foreign policy he will choose by testing his seven state factors? For instance, if the swamin's state factors are better functioning and more intact than that of the rival state the swamin can make use of war and he can easily win the war, or he can also make a treaty with other states in which the surrounding of this state will be confirmed. As already mentioned, seven prakrti are the main determinant factors, among which the swamin will take six measures of foreign policy. Kautilya also said 'war' is the last option, especially the open war. Kautilya encourages the ruler to better use spies and agents to weaken the enemy's state. The spies and diplomatic agents are highly crucial for the concept of Sadgunya because, through their activity, the ruler gets the information about the other state.

Upaya is not the original concept by Kautilya. The existence of this concept can be found in ancient Hindu sacred books Ramayana and Mahabharata, as mentioned earlier (Liebig, 2014). There are four main stream upaya in total. The four Upaya is an instruction on how to get one's will work even against the resistance of others (Gautam, 2013a). The first upaya is saman, and it means kindness or amicability. It also includes compliments, flatteries, nicely spoken words to get ones will. In the case of a state, saman also includes treaties that are temporary and can be broken anytime. Likewise, it doesn't require any financial resources. The next one is dana means gift. By gift, Kautilya suggests every kind of gift, including granting of lands or even corruption. This one requires some material resources. Bheda means discord and breeding the seed of friction between two different actors and push one's will through.

There is an explicit instruction for the king how to use bheda to end protest or move against the king. The last upaya is danda means punishment. Unlike the other three danda can turn into violence. It can be silent punishment by using criminal law, or in the case of foreign policy, it can be war with another state. The application of this four upaya can take place in internal strategy as well as foreign policy. Kautilya also mentions there is the hierarchy of upaya, and the king has to use cost-benefit analysis but not listen to one's instincts while using it. Moreover, the king should use the other three Upaya before using danda. And only if when he doesn't reach his goal, then he can use danda (Boesche, 2002; Kanwal, 2016).

There is another concept by Kautilya in his Arthasastra, Rajmandala, and it means 'circle of kings' and people connect it with the statement, 'every neighboring state is an enemy, and the enemy's enemy is a friend.' However, this system is much more complicated than it appears. Rajmandala a system of concentric circles in which vijigishu (conqueror or ruler) and his territory lie at the center. His (King) direct neighbors surround him, and they are regarded as ari (enemy) because they all share at least one border with the vijigishu's state. Those states defined as ari are surrounded by other states, which are called mitra (ally, friend), and those are more friendly with the vijigishu because they don't share a border with him, so at the moment there is no reason for the dispute. At the moment, the vijigishu has conquered one of the neighboring states; the situation changes because a former mitra turns into ari (Sihag, 2016).

There are two other kinds of states. One is madhyama (Middle Ruler), which is not directly related to the vijigishu's foreign policy. However, this state shares a border with vijigishu and ari, but they have a neutral position (Mohanty \& Das, 2017). As well as, another powerful stateis not directly involved in the circumstance because they are part of the circles but not physically attached to the loop because they are too far away. From the vijigishu's point of view, they are regarded as bystanders; these are the udasina. It is not useful to take the Rajamandala system as a static concept because, for Kautilya, the relations between states were regarded to be in constant flux and these relations, might they be friendly or hostile, only have a temporarily limited quality. They are entirely fluid (Gautam, 2013b). 
From the above discussion, it is now evident that every concept by Kautilya in his Arthasastra is dependent on each other. This current paper will not discuss all the ideas by Kautilya; instead, the major three (Upaya, Sadgunya, and Prakrti), according to the hypothesis of the current study, change in any one of these concepts will affect the other two.

\section{Three major concepts and their inter-dependency -}

From the above discussion, it is now you can assume that there is dependency among the concepts by Kautilya in his Arthasastra. As already mentioned, in this current paper, the researcher will focus on three major concepts by Kautilya. In this section of the article, the researcher will try to analyze the details of the three major ideas (Upaya, Sadgunya, and Prakrti) and find their dependency on different aspects.

What makes a state more robust, more stable? According to Kautilya, the comprehensive framework of prakrti make a stronger and more stable (Buzan, 1991; and Mohanty \& Das, 2017). There are seven prakrti, and based on the prakrti, the state can be considered as strong, or these prakrti can provide the base for expansion and progress. Thus, weaknesses in any one of them might impact the functionality of the state or even make it a failure state (Liebig, 2014).

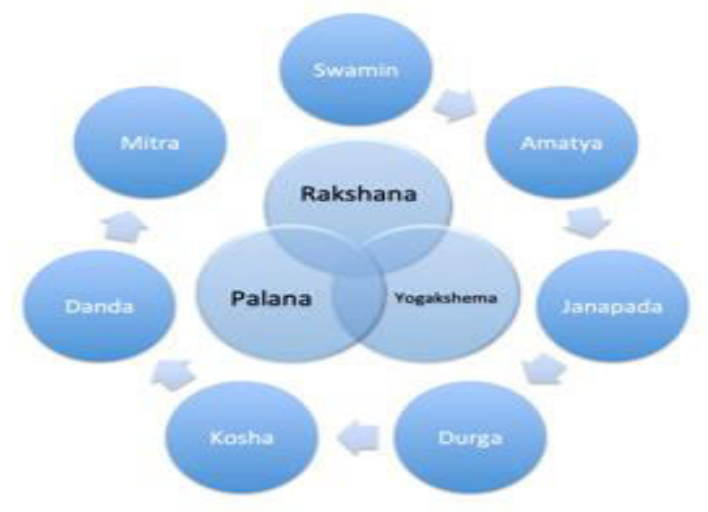

Fig 2: Circular Representation of Kautilya's Saptanga/Prakrti (More, 2015)

From the figure, you can see the seven prakrti and their hieratical order of prakrti, and that starts with swamin leadership and ends with mitra (alliance) (More, 2015). Kautilya also mentioned that the progress of the prakrti leads to the 'king's duty' or 'rajdharma' rakshana (protection), palana (welfare),

UniversePG I www.universepg.com and yogakshema (the rule of law) (ibid). Based on the theory of social contract, if the king obeys his duty, and that gives him the legitimacy to rule the state legally.

"In Kautilya's basic view of power as the capacity to use force as the means to enforce one's will against the resistance of others be it within a state or against another state - there is an evident homology with Max Weber, Plessner, and Morgenthau" (Liebig, 2014; Mohanty \& Das, 2017). Also, this power is exclusive to the state's capacity to use force. And this state power is the aggregate result of the seven state factors. Besides, the state is not only determined by one part but also the other six power factors. The powerful state is determined by the given status and the developmental trend of all seven prakrti.

Moreover, Kautilya assigns a relative weight to the seven state factors. For example, a good ruler can bring the other six consecutive factors into good condition; besides, a lousy ruler will do the worst. The ranking of the prakrti is logical, substantive hierarchy, and generative principle. The first state factor swamin (ruler) is the generative condition of the state factor amatya (institutions), and without a ruler, there will be no institutions. Ruler and institutions constitute the institutional framework for the janapada (rural people) living and working therein (Liebig, 2014; Liebig \& Mitra, 2017).

Besides, the first three state factors are the prerequisite of the state factor durga (fortress), residence, and capital. And in the capital, there is the next state factor kosa (treasury) so that it is safe and also to ensure the flow of the tax revenue (Shahi, 2019).

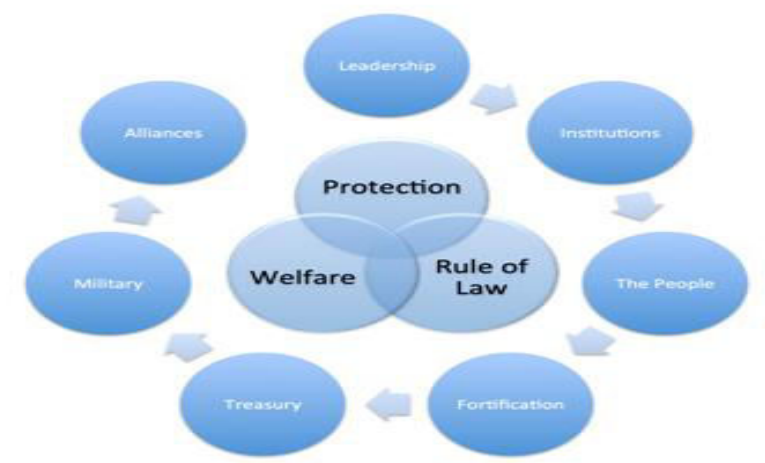

Fig 3: Prakrti (Elements of the State) Modern Day State System (More, 2015). 
A well-stocked treasury is vital for financing danda (armed forces). And these six prakrti are essential for successfully conducting the mitra (foreign policy and alliance). Now it is evident all the prakrti are logically and practically interdependent (Liebig, 2014; Prabhu, 2019; and Shahi, 2019).

To get an objective assessment of seven state factors, Kautilya proposes a census system. Evaluating and estimating his power and foreign states, the king will take the decision. In this system, geographically and demographically, big states might find that they have small military and small treasury (More, 2015; Prabhu, 2019). Also, a territorially and the demographically small state can become a powerful state. If the state factors leadership and institutions are of excellent quality will expand the economy in the rural people and the city, thus increasing tax revenue allowing armed forces to be upgraded and conducting a wise foreign policy (Liebig, 2014; Prasad, 2018).

The saptanga theory (seven prakrti) provides an assessment of one's resources and capabilities on one side and the skills of others on the other side. The target is to estimate the situation, and at the bottom is the correlation of forces between states. The main idea is to eliminate non-reflective, impulsive, and arbitrary action in foreign policy by the king (Liebig, 2014). And via the saptanga theory, Kautilya establishes substantive and objective criteria for assessing the correlation of forces between the states, and this assessment and that will determine which foreign policy measures the ruler should select (Liebig \& Mitra, 2017).

Kautilya offers six basic approaches in foreign policy the sadgunya theory. And the indirect basis of this theory is seven prakrti. Depending on the objective assessment of the correlation of forces the following are the strategies in foreign affairs for the ruler (Liebig, 2014)

- samdhi (peace)- the rival state is more robust and will remain so in the foreseeable future

- vigraha (war)- the rival state is vastly inferior in power

- asana (neutrality)- the correlation of forces are balanced
- yana (war preparation, coercive diplomacy)one' sability is rising vis-à-vis the rival state

- samsraya (alliance building)- the rival state's power is rising faster than one's own

- dvaidhibhava (diplomatic double game)- the constellation among rivals and allies is very fluid

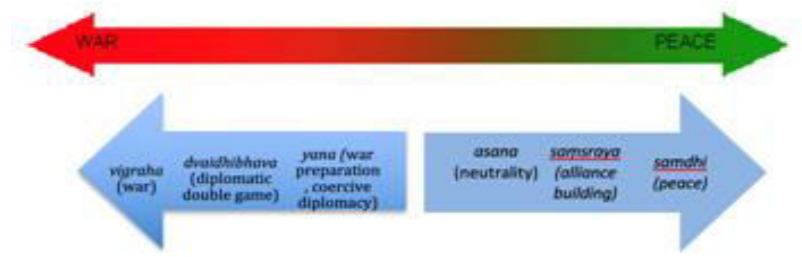

Fig 4: Six potential foreign policy choices for the King (More, 2015)

As Kautilya mentions, these six measures are the action strategies in foreign policy because of the different situations in the country. That means, due to the dependence and the status of the seven prakrti, the king will decide which foreign policy should be taken. Besides, the saptanga theory provides the benchmark for the correlations of forces between the rival states, and this correlation of forces are the determinant of which foreign policy measures should be chosen. Kautilya says, using the seven prakrti and six methods of foreign policy, the ruler should seek to progress from decline to stable condition and from stable condition to advancement position (Shahi, 2015).

According to Boesche, sadgunya are the 'Pendulum theory of history' in which the country passes through three phases, and they are - decline, stability, and advancement (Boesche, 2002). Kautilya says when the country is in fall, make peace; when prospering makes war; if equal in power remain neutral; depilated in power seek shelter with the help of dual policy and when blessed with excellence prepare for war (More, 2015).

Kautilya also mentions that mistakes by the king and natural calamities can put the kingdom from advancement and stability position to decline the position. And the policy makers/ king is making policies for the state Kautilya talks about 'divine' intervention for good fortune and misfortune. Because anything can happen in any state at any time (Prasad, 2018). 
Kautilya also mentioned four basic conflict resolution methods in his book for bring peace among the conflicting parties or state (Adityakiran, 2015). There are also three advanced conflict resolutions methods described in Arthashastra. However, as already mentioned, these methods are not initially from Kautilya, but they are from Sukra Niti, Agni and Matsya Puranas, and Nitisara of Kamanadaki, besides many other texts (Gautam, 2013b). Hence, exploring the saptanga and shadgunya combined with a suitable upaya, vijigishu can ensure that he achieves his national goal of yogakshema, lokasangraha, and becoming a chakravartin ruler (Adityakiran, 2015; Ray, 2015).

So, what are this upaya and how those works according to Kautilya? Since the political world is divided between conflicted and anarchical, and in this state of affairs, the ruler has to act politically (Liebig, 2014; Liebig \& Mitra, 2017). In addition, politics is the issue of enforcing one's own will upon another or others. To use one's own will against resistance, there are four methods of political behavior. They are called four Upaya (Liebig, 2014)

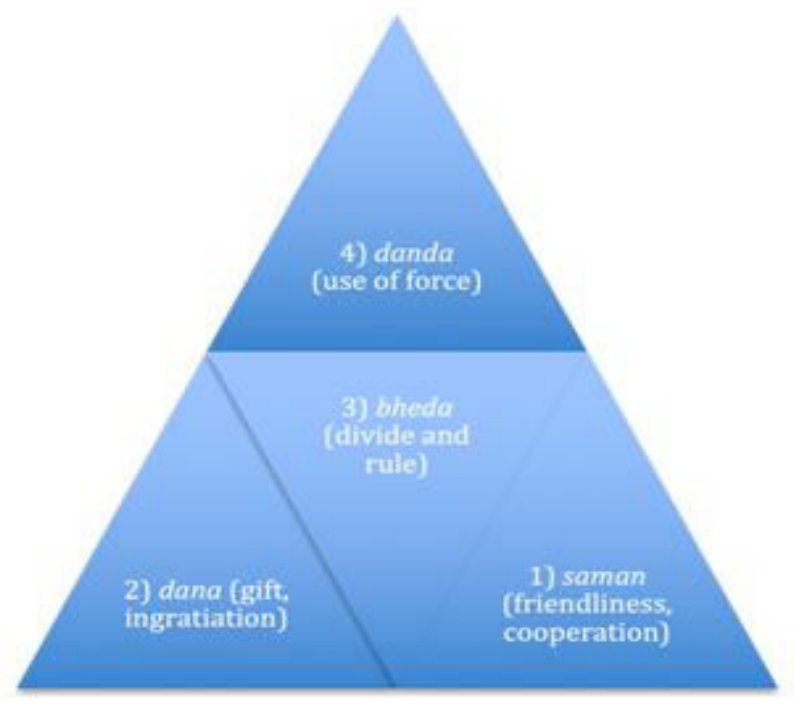

Fig 5: Hierarchical positions off our upaya for Conflict Resolution by Kautilya (adopted by the researcher).

There are three other advance methods, and they are upeksha stepping back, ignoring deliberately, being indifferent, maya passive deception and aindrajala active deception. Kautilya recommended different upaya for different situations and places. In the case of appeasing the military, people in the countryside or UniversePG I www.universepg.com citizens in the city dana, bheda, and mayaupaya can be used. However, in the case of the neighboring prince or forest chiefs, bheda, danda, and aindrajalaupaya are recommended methods. Now you can see that depending on the condition of the prakrti by Kautilya, the ruler should choose which kind of upaya should be used. Besides, in the case of foreign policy measures, the ruler should decide which upaya he will use for which strategy of foreign policy (Prasad, 2018; Set, 2015).

Measurement scale for showing the dependency among three concepts - From the above discussion, it is now demonstrated that the three major concepts of Kautilya are interconnected, and they have substantial interdependency. At this point, the researcher will formulate a general measurement scale for showing the dependency among the three concepts. Boesche mentioned that the state always passes through three phases- decline, stability, and advancement (Boesche, 2002; Saad \& Wenxiang, 2020).

The researcher is keeping that in mind if the researcher starts with seven prakrti by Kautilya. For instance- if the janapada (rural population) is satisfied, that means this state factor is in a 'stable' position, and the researcher will measure this position with ' 0 '. However, if they are dissatisfied, then the researcher as to consider this state factor is in the 'decline' position and will measure this position with ' -1 '.

Similarly, if this state factor (rural population) is happy with the king, then you can consider this state factor is in the 'advancement' position and measure this position with ' 1 '. And for measuring the status of the state factor, Kautilya has mentioned different methods, including secret agency, survey, census, and much more. Now you can apply this method with every prakrti or state factor.

And according to the theory of saptanga, sadgunnya, and correlations of forces, the position, and status of the prakrti or state factors are the determinants of the six foreign policy measures. For example- if all the prakrtiis in decline position according to the measurement scale, the state power will be in '-7', and the ruler should make peace (Saad \& Wenxiang, 
2020). However, if all the prakrti are in advance position and according to the measurement scale, the state power will be '7', and the king will be able to make war. If all the Prakrti change their position and are in a stable position, the state power will be ' 0 ' according to the scale, and a ruler will have to neutral according to sadgunnya.

Furthermore, if three prakrti are in advance position (3), two are in decline position (-2), and one is in the stable position ( 0$)$, and that will make the state power total of '2,' and the ruler has to prepare for war. Likewise, if the four prakrti are in decline position ($4)$, one is in advance (1), and two are stable (0), and that will make a total state power of ' -3 ,' and the king has to seek for protection.

Besides, there can be a different combination of state factors among decline, advance, and stable. Still, you have to look at the number of the total, and based on the number, you will be able to decide which kind of foreign policy measures the ruler should choose.

Furthermore, according to the understanding of Max Weber's 'political struggle' or 'power' is the issue of enforcing one's own will upon others or others (Liebig, 2014). Toimpose one's will against resistance, Kautilya sees four - no more and no less - basic methods of political behavior - the four upaya. And with the help of the scale, you will be able to determine, in which condition the ruler should use which upaya. For example- if all the state factors are in decline position and that means the total state power is ' -7 ', then the ruler should use saman (friendliness or cooperation) as upaya to rule or solve the existing problem inside or outside of the state. Correspondingly, if all the state factors are in advance position and that means the total state power is ' 7 ' and the ruler can use danda (use of force) as upaya to rule or solve the existing problem and conflict resolution accordingly.

Likewise, if five state factors are changed in advance position (5), and one is in decline (-1). One is in a stable position, then that makes the state power a total of ' 4 ,' and the ruler can use bheda (divide and rule) as upaya to solve the move against him or to rule. It means that the change in prakrti has affected the decision of the king on Upaya (Liebig \& Mitra, 2017).

On the other hand, if the state power is ' -2 ', then the rulers have to use dana (gift, ingratiation) to reach the goal. From the above discussion, it is now evident that the change in any subcomponent of the three major concepts will affect the others. The following table will show the tabular representation of dependency on the three critical concepts by Kautilya.

Table 1: Measurement Scale of Kautily's Three Major Concepts.

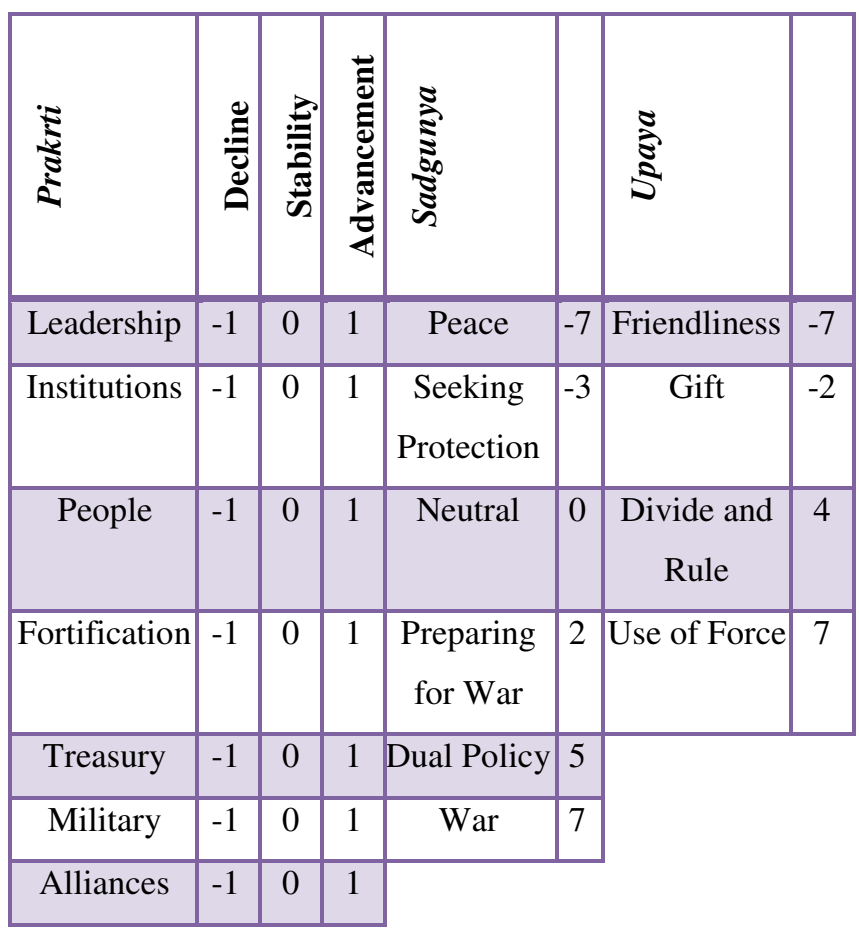

Source: Prepared by the researcher

Reference from 1962 Sino-Indian War - "India's China War" was, mainly, the major military clash of 1962 on the Indian-Tibetan border (Spruyt, 2020). At this point in the paper, the researcher will try to evaluate the decision of going to war from the Indian side, considering the state factors by Kautilya and measuring them with the measurement scale from this paper.

Let's take the example as the first Prakrtiswamin (leadership). During that time, Prime Minister Jawaharlal Nehru (political realism) in the first place believed in peaceful co-existence and then changed policy to defending the border (Apri, 2004; Mathai, 
2013). According to his 'Discovery of India,' it is now evident that he knew about Kautilya. He (Nehru) was not wrong about his prediction since he believed in peaceful co-existence. He thought that China would not attack India. In this case, according to the measurement scale, the leadership is in an advancement position (1) (Joshi, 2019).

He was the elected leader since 1947 as Prime Minister Nehru has substantive control over the second state factor amatya (institutions, ministers). However, others warned him of the cabinet about China policy not only by Vallabhbhai Patel but also very pro-China advisors like Krishna Menon. In this case, if you consider the status of this status of state factor, it was in decline (0). The third state factor, janapada (the rural people) were criticizing Nehru for giving into China and that led to 'Forward Policy.' Besides, there was a change in public mode and within parliament about China. Considering the facts, the janapada was also in decline (-1). Durga (fortress) is the national infrastructure, and it is evident that after liberation in 1947, there was a nationwide riot in India. The national infrastructure was in a condition of decline (-1) until the war took place.

Moreover, kosha (treasury) of India was not protected enough, and in 1962, the per capita income of India was 90.00 USD. By comparing the fact, it is evident that the kosha was in decline status (-1) too. Besides, danda (military, secret service) is another critical factor for the 1962 Sino-Indian War. India intended to derive China out from the Indian-claimed territory. However, during that time, the literature suggests that Nehru was indifferent about military development. Also, for secret and intelligent information, India had to depend on the USSR and USA secret services (IDSA, 2012). Furthermore, India didn't use its Air Force during the war. Now it is depicted that the dandaprakrti was in decline (-1) for India during that time before going to war. Last but not least, mitra (alliances) of India was busy with other events (Joshi, 2019). In 1962 at the very same time, the big world powers and so-called friends of India were busy with the 'Cuban Missile Crisis.' In addition, Nehru perceived that Russia and the USA would come forward against China's attack on India. In addition, due to the cold war, the world powers were also divided into two blocks, and India followed the neutral law and formed the Non-Alliance Movement (NAM). Considering all these facts now, it is evident that the mitra was also in decline (-1).

Now, if you consider the measuring scale and you will find a total of ' -4 '. And according to the scale, with this state power during India should have used asana (neutral) or samshraya (seeking protection) as the foreign policy measure. And for solving the problems, including national and international interest, India should have used sama (friendliness, cooperation) or dana (gift, ingratiation) according to measurement scale. What could be the real steps that can be another issue of discussion?

\section{CONCLUSION}

The book Arthasastra by Kautilya is a rulebook for the rulers. It was written several centuries before in this Indian subcontinent. Nonetheless, it is time and context-free, but there are arguments about it. However, from the above discussion, it is evident that the three major concepts by him are significantly interlinked and interdependent. In addition, considering the status of the prakrti, any political analysts can suggest which kind of foreign policy measure should be used for foreign relations and which type of method should be used for mitigating problems/ events and conflict resolutions in national or international spears. And the measurement scale is another attempt to show the positive and negative correlations of forces and determining the sadgunhya and saptanga. And finally, there is a discussion the 1972 Sino-Indian War. The war is one of the India's most devastating and cruel past. In that war India was defeated by China by several means. Nevertheless, the war came to an end within a month. In the above discussion the researcher has discussed the war using the measurement scale and tried to analyze the event of the '1962 Sino-Indian War'. The researcher has suggested what should have done instead of going to war according to Kautilya and the 'measurement scale' of three major concepts. Using the major three concepts of Kautilya and the measurement scale the researchers can do some analysis with the other events like 1962 Sino-Indian War. 


\section{ACKOWLEDGEMENT}

The researcher would like to thank Dr. Michale Liebig for his unwavering support to formulate the idea of this current paper. Sadly, he died on 15 April 2020; May his soul rest in peace. He would have been delighted if he could see this paper getting. The researcher would like to dedicate this paper to his name. The researcher of course is solely responsible for the information contained in this paper.

\section{CONFLICTS OF INTEREST}

The researcher declares no possible conflict of interest concerning the study, data collection \& analysis, authorship, and/or publication of this present article.

\section{REFERENCES}

1. Adityakiran G. (2015). Kautilya's Pioneering Exposition of Comprehensive National Power in the Arthashastra. New Delhi (New Delhi): Institute for Defence Studies and Analysis. https://idsa.in/system/files/book/book_Indigenou sHistoricalKnowledge Vol-I.pdf

2. Ahamed A, Sikdar MM, and Shirin S. (2019). Bangladesh-East Asia relations in the context of Bangladesh's look east policy. Br. J. Arts Humanit., 1(4), 1-13. https://doi.org/10.34104/bjah.019.0113

3. Apri C. (2004). Born in Sin: The Panchsheel Agreement, the Sacrifice of Tibet. New Delhi: Mittal Publications. ISBN 817099974X, 97881709997442.

4. Boesche R. (2002). The First Great Political Realist: Kautilya and His Arthashastra. Oxford: Lexington Books. ISBN-0739106074, 9780739106075.

5. Boesche R. (2003). Kautilya'sArthas' - sastra on War and Diplomacy in Ancient India. The Journal of Military History, 67(1), 9-37. https://doi.org/10.1353/jmh.2003.0006

6. Buzan B., (1991). People, States and Fear: An Agenda for International Security Studies in the Post Cold War Era. London: Harvester Wheatsheaf. ISBN 0955248817, 9780955248818

7. Gautam P. K. (2013a). One Hundred Years of Kautilya's Arthashastra, Delhi: IDSA. https://idsa.in/system/files/monograph20.pdf

8. Gautam P. K. (2013b). Understanding Kautilya's Four Upayas, New Delhi: Institute of Defence Studies Analysis.

https://idsa.in/idsacomments/UnderstandingKaut ilyasFourUpayas_pkgautam_200613

9. Hillebrandt A. (1923). Altindische Politik . In: s.l.: Jena: Fischer.

10. Hossain MK. (2020). Bhagabania, Nigamananda and Baha'i of Jashore in Bangladesh: A Study of Women, Asian J. Soc. Sci. Leg. Stud., 2(2), 41-46. https://doi.org/10.34104/ajssls.020.041046

11. IDSA, (2012). Interview with Marshal of the Indian Air Force, New Delhi: Institute of Defence Study Analysis.

https://idsa.in/jds/6 4 2012 InterviewwithMars haloftheIndianAirForce_ShrutiPandalai

12. Joshi A., 2019. Strategic Wisdom from the Orient: Evaluating the Contemporary relevance of Kautilya's Arthashastra and Sun Tzu's Art of War. Strategic Analysis, 43(1), 54-74.

https://doi.org/10.1080/09700161.2019.1571747

13. Kainiraka S. (2016). From Indus to Independence - A Trek through Indian History. First Ed. New Delhi: Vij Books India Pvt. Ltd. ISBN-9385563149, 9789385563140.

14. Kanwal G. (2016). The New Arthashastra: A Security Strategy for India. First Ed. New Delhi: Harper Collins Publishers, India.

15. Kinzinger A. (2015). Gandhi as political realist in the tradition of Kautilya, Heidelberg: South Asia Institute.

16. Liebig M. (2014). Kauțilya's Arthaśāstra: A Classic Text of Statecraft and an Untapped Political Science Resource. Heidelberg Papers in South Asian and Comparative Politics, 74, 1-21. https://doi.org/10.11588/heidok.00017144

17. Liebig M. \& Mitra S. K. (2017). Kautilya's Arthashastra: An Intellectual Portrait: the Classical Roots of Modern Politics in India. First ed. Baden-Baden: Nomos Verlagsge sellschaft mbH \& Co. KG Waldseestraße 3-5. ISBN 3848727641, 9783-848727643

18. Mathai M. V. (2013). Nuclear Power, Economic Development Discourse and the 
Environment: The Case of India. Taylor \& Francis. ISBN 9780415629164.

19. Modelski G. (1964). Kautilya: Foreign Policy and International System in the Ancient Hindu World. Cambridge: American Political Science Association. https://doi.org/10.2307/1953131

20. Mohanty A. \& Das G. P. (2017). Revisiting the Arthashastra: An Approach to Emotional Intelligence. Parabandhan: Indian Journal of Management, 10(5). https://doi.org/10.17010/pijom/2017/v10i5/114253

21. More S. (2015). Kautilya on State Fragility in Contemporary Security Environment. New Delhi (New Delhi): Institute for Defence Studies and Analysis.

22. Prabhu M. (2019). Chanakya Kautilya: Understanding the Colossal Genius. New Delhi: The Thomson Printing Press Ltd.

23. Prasad J. (2018). Kautilya's Arthashastra: an intellectual portrait: the classical roots of modern politics in India. Strategic Analysis, 42(4), 451-452. https://doi.org/10.1080/09700161.2018.1482621

24. Ray K. (2015). Varieties of Mitras and Varieties of Sandhis in Early India: Kautilya's Arthashastra and other Texts. New Delhi (New Delhi): Institute for Defence Studies and Analyses.
https://idsa.in/system/files/book/book_Indigenou sHistoricalKnowledge Vol-I.pdf

25. Saad M. \& Wenxiang L. (2020). National Security in Kautilya's Arthashastra: A Content Analysis. Journal of Humanities and Education Development (JHED), 2(2), 129-140. https://doi.org/10.22161/jhed.2.2.8

26. Set S. (2015). Ancient Wisdom for the Modern World: Revisiting Kautilya and his Arthashastra in the Third Millennium. Strategic Analysis, 39(6), 710-714. https://doi.org/10.1080/09700161.2015.1090685

27. Shahi D. (2015). Arthashastra Beyond Realpolitik: The 'Eclectic' Face of Kautilya. New Delhi (New Delhi): Institute for Defence Studies and Analysis.

https://idsa.in/system/files/jds/jds_10_2_2016_k autilya-s-arthashastra.pdf

28. Shahi D. (2019). Kautilya and Non-Western IR Theory. First ed. Cham: Palgrave Macmillam. ISBN 3030017281, 9783030017286.

29. Sihag B. S. (2016). Kautilya's Arthashastra: A Recognizable Source of the Wealth of Nations. Theoretical Economics Letters, 6(1), 59-67. https://doi.org/10.4236/tel.2016.61008

30. Spruyt H. (2020). The World Imagined. First ed. Cambridge: Cambridge University Press. ISBN-1108491219, 9781108491211.

Citation: Saha KK. (2020). Dependency among Kautilya's three major ideas: Upaya, Sadgunya, and Prakrti, Br. J. Arts Humanit., 2(2), 24-35. https://doi.org/10.34104/bjah.020024035 @) 